\title{
A Planetary Perspective of Earth Systems Sustainability: Reframing Climate Change Implications from Agricultural Adaptations in Maya Milpa Farming Communities in Belize
}

\author{
Kristin Drexler \\ American Public University System
}

\begin{abstract}
In a case review of climate-smart agriculture practices in Mayan milpa farming communities in Belize (Central America), this paper reframes how small-scale agriculture practices can influence larger Earth systems sustainability. In what has been a sustainable form of farming for hundreds of years, the milpa has become less sustainable due to global climate change, forest loss, soil degradation, population growth, and other factors. This article reviews the findings of a 2020 study of positive socio-ecological systems (SES) influences-environmental, economic, socio-cultural, and technological-from climate-smart practices on local resource sustainability. SES considers several multidisciplinary linkages of human and ecological factors in the agroecological system. SES considers several multidisciplinary linkages of human and ecological factors in the agroecological system. SES influences from small-scale climate-smart agriculture (CSA) practices can have both micro-scale impacts as well as macro-scale implications for SES sustainability and food security. Understanding the implications of small-scale farming on larger Earth systems can inform global climate change mitigations and government policy and action needed to promote CSA practices. This is important for the resilience of vulnerable populations such as Belizean milpa farming communities and others who rely directly on resource sustainability for their food and livelihood security.
\end{abstract}

Keywords: Climate-smart agriculture, socio-ecological systems, planetary, milpa, sustainability 


\section{Una perspectiva planetaria de la sostenibilidad de los sistemas terrestres: replanteamiento de las implicaciones del cambio climático a partir de adaptaciones agrícolas en comunidades agrícolas mayas milpa en Belice}

\section{RESUMEN}

En una revisión de caso de las prácticas agrícolas climáticamente inteligentes en las comunidades agrícolas de milpas mayas en Belice (América Central), este documento replantea cómo las prácticas agrícolas a pequeña escala pueden influir en la sostenibilidad de los sistemas terrestres más grandes. En lo que ha sido una forma de agricultura sostenible durante cientos de años, la milpa se ha vuelto menos sostenible debido al cambio climático global, la pérdida de bosques, la degradación del suelo, el crecimiento de la población y otros factores. Este artículo revisa los hallazgos de un estudio de 2020 sobre las influencias positivas de los sistemas socioecológicos (SES) —ambientales, económicos, socioculturales y tecnológicosde las prácticas climáticamente inteligentes sobre la sostenibilidad de los recursos locales. SES considera varios vínculos multidisciplinarios de factores humanos y ecológicos en el sistema agroecológico. SES considera varios vínculos multidisciplinarios de factores humanos y ecológicos en el sistema agroecológico. Las influencias del SES de las prácticas de agricultura climáticamente inteligente (CSA) a pequeña escala pueden tener impactos tanto a microescala como implicaciones a macroescala para la sostenibilidad del SES y la seguridad alimentaria. Comprender las implicaciones de la agricultura a pequeña escala en los sistemas terrestres más grandes puede informar las mitigaciones del cambio climático global y las políticas y acciones gubernamentales necesarias para promover las prácticas de CSA. Esto es importante para la resiliencia de las poblaciones vulnerables, como las comunidades de agricultores de milpas de Belice y otras que dependen directamente de la sostenibilidad de los recursos para su seguridad alimentaria y de sus medios de vida.

Palabras clave: Agricultura climáticamente inteligente, sistemas socioecológicos, planetario, milpa, sostenibilidad 


\title{
从地球视角看待地球系统的可持续发展：从伯利兹玛雅 米尔帕耕种社区的农业适应过程中重新定义气候变化意 义
}

摘要

\begin{abstract}
通过对中美洲伯利兹玛雅米尔帕耕种社区的气候智能型农业 实践进行案例回顾，本文重新定义了小型农业实践如何能 影响更大的地球系统的可持续发展。几百年来，传统米尔 帕耕种实践一直是可持续的，但如今可持续性却因一系列 因素而减少，包括全球气候变化、森林减少、土壤退化、 人口增长, 以及其他因素。2020年的一项研究发现, 气候 智能型实践对地方资源的可持续发展具有积极的社会-生态 系统（SES）影响（包含环境、经济、社会一文化以及技术方 面），本文对此进行了审视。SES考量了农业生态系统中人 类因素和生态因素的多学科联系。从小型气候智能型农业 (CSA) 实践中产生的SES影响能为SES的可持续发展以及粮 食安全产生微观影响和宏观影响。理解小型农业对更大的地 球系统产生的影响能促进全球气候变化缓解, 并影响推动 $\mathrm{CSA}$ 实践所需的政府政策及行动。这对脆弱群体的复原力而 言是重要的, 例如伯利兹的米尔帕耕种社区和其他直接依赖 资源可持续发展以获取粮食安全和生计安全的那些群体。
\end{abstract}

关键词: 气候智能型农业, 社会-生态系统, 地球, 米尔帕, 可持续发展

\section{Introduction}

This paper reviews the Drexler (2020) findings of positive socio-ecological system impacts from climate-smart agriculture practices in Mayan milpa farming communities in Belize, Central America and reframes it to a planetary perspective of how these adaptations can influence larger Earth systems sustainability as a space environment. Earth systems integrate biophysical cycles and human (e.g., socioeconomic) interactions in the atmosphere, hydrosphere, cryosphere, biosphere, geosphere, and anthroposphere "in both spatial-from local to global-and temporal scales, which determine the environmental state of the planet within its current position in the universe" (Rockström, et. al., 2009). Thus, human communities are a part of, and not apart from, the Earth system; humans experience impacts from climate change and can be more vulnerable to associated increases in resource 
loss and degradation (Drexler, 2020; Flint, 2015; Oremo, 2013; Young, 2008).

Planetary-level impacts from climate change have been observed from space for more than 40 years; these observations are central to monitoring and understanding how the dynamics of the Earth systems work (Durrieu \& Nelson, 2013; Johannessen, 2009). Small-scale agriculture can also have planetary implications on Earth systems sustainability (Altieri, 2008). This paper will examine socio-ecological systems (SES) impacts of climate-smart agriculture (CSA) adaptations of milpa farming to reframe the issue to a planetary context.

SES considers multiple integrated human and ecological factors and linkages in the agroecological system. For example, adopting CSA practices in small-scale milpa agriculture has environmental, economic, socio-cultural, adaptive technology, and governance influences on local resource sustainability (Drexler, 2020; ERSI, 2008; Mazumdar, 2008). The nature of SES, especially from a planetary perspective, is inherently holistic and involves multi-disciplinary factors (Méndez, Bacon, \& Cohen, 2013). Applying SES principles from one small region to the larger SES can and inform reasonably foreseeable climate change impacts (on both micro and macro levels) and promote mitigation policies in other regions of the globe (Uusitalo, et. al., 2019), with implications on resilience and food and livelihood security in more vulnerable and marginalized communities (Drexler, 2020; Tandon, 2014).

\section{Planetary Sustainability}

A s defined by the National Aeronautics and Space Administration (NASA) the term "planetary sustainability" includes multi-perspectival factors (ecological, economic, social) includes three global visions (NASA, 2014); this paper will examine the first two as they directly relate to climate change impacts on planetary sustainability: 1. All people have access to abundant water, food and energy, as well as protection from severe storms and climate change impacts; and 2. All people have healthy and sustainable worldwide economic growth from renewable products and resources. Planetary sustainability also recognizes two sustainability conditions to determine safe operating space for human survival on Earth: 1. Respecting Earth system boundaries, such as biodiversity, atmospheric composition, freshwater resources, and other planetary boundaries (Galli \& Losch, 2019; Rockström, et. al., 2009) and 2. Expanding our instruments and people into space (Galli \& Losch, 2019; Pass, et. al., 2006).

Directly related to global policy toward planetary sustainability, there are 17 United National Sustainable Development Goals (SDGs), with an $18^{\text {th }}$ potential goal (Figure 1) called "Space Environment” (Galli \& Losch, 2019). The SDGs demonstrate multi-perspectival and socio-ecological system symbiosis, applicable to both local and planetary levels. 

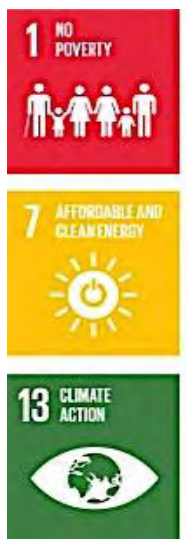
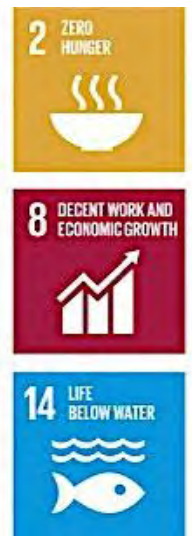
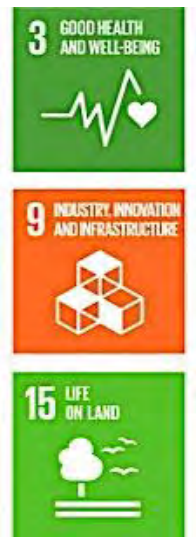
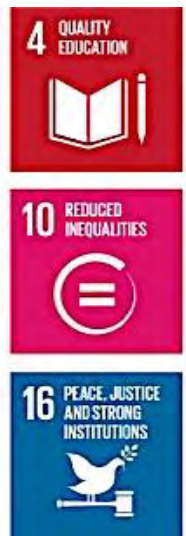
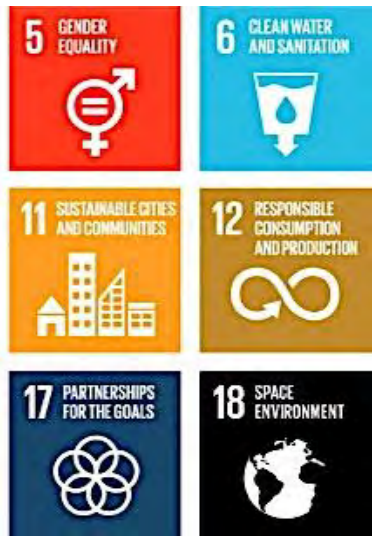
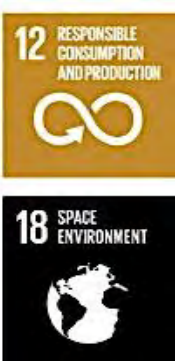

Figure 1. The UN SDGs with a potential 18th goal added (Galli \& Losch, 2019).

Most SDGs are directly linked with global food systems and food security. Transformative policy and action to include the SDGs in examining non-food (i.e., alternatives to fossil fuels) and food-related strategies (less meat consumption, promoting government Extension services) are needed to facilitate climate-smart agriculture practices, resource sustainability, and food security for a growing global population (Campbell, Hansen, Rioux, Stirling, \& Twomlow, 2018; Chaudhary, Gustafson, \& Mathys, 2018; Pérez-Escamilla, 2017).

\section{Climate Change, Food}

\section{Insecurity, and Climate Justice}

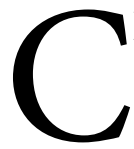

limate change is one of the greatest threats to the people and economies of Earth (Marino, et. al., 2016; Vermeulen, Campbell, \& Ingram, 2012). Agriculture is a key driver contributing to climate change (Campbell, et. al., 2017; FAO, 2013; Uusitalo, et. al., 2019). Climate change adversely and disproportionately impacts the rural poor who depend directly on natural resources for their food and livelihood security; these impacts exacerbate existing socio-economic (socio) and biophysical (ecological) conditions (Adger, 2003; Aminzadeh, 2006; John \& Firth, 2005; Morton, 2007; Oremo, 2013; Schmidhuber \& Tubiello, 2007; Vermeulen, Campbell, \& Ingram, 2012). Climate change is not just an environmental issue, but increasingly an economic, socio-cultural, and justice issue, with implications on community resilience, food security, health, and livelihood security (Aminzadeh, 2006; Vermeulen, Campbell, \& Ingram, 2012). Improvements in agriculture and the overall food system can be significant step toward planetary sustainability, food security, and climate justice (Campbell, et. al., 2017; Wezel, et. al., 2009).

\section{Socio-Ecological Systems (SES) Framework}

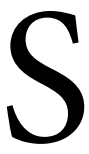

ocio-ecological systems (SES) is a theoretical framework which can examine multi-disciplinary and 
complex issues such as climate change impacts on agricultural landscapes and human communities (Drexler, 2020; Oremo, 2013). Climate change and food security studies are complex, systemic, cumulative, and intertwined with human systems (Molnar \& Molnar, 2000). SES is a flexible framework which considers the interrelationships, linkages, and synergies between multiple trans-disciplinary factors (i.e., social, economic, environmental, cultural, governance, health, justice) and community-based partnerships and adaptive management (Olsson, Folke, \& Berkes, 2004; Ostrom, 2009; Parrott, Chion, Gonzalés, \& Latombe, 2012). A socio-ecological system is a linked network where an impact on one part of the system-climate change impacts from storm erosion, for example-can affect the larger system, such as food security and farmer livelihoods (Lal, 2008; Levasseur \& Olivier, 2000; Molnar \& Molnar, 2000; Selomane, Reyers, Biggs, \& Hamann, 2019). Understanding these system relationships-and how each factor functions in the complex whole of the SES-is important as each decision a farmer makes to adopt CSA practices can advance the entire milpa agriculture system further (Koutsouris, 2008; UC Davis, n.d.).

A paradigm shift toward SES systems-thinking, described by Ratima, Martin, Castleden, and Delormier (2019) as a more "Indigenous way of thinking about the interconnected and interdependent web of the natural world" is needed to examine and understand complex SES linkages and dynamics, to manage resources and sys- tem vulnerabilities, and to facilitate policy changes on sustainability (Drexler, 2020; Sikula, Mancillas, Linkov, \& McDonagh, 2015). A systems perspective is important in making climate mitigation and adaptation policies which contribute to positive outcomes of sustainable food systems; considerations should include equity, resilience, renewability, responsiveness, transparency, scale, and evaluation as well as SES indicators such as food security, health, environmental integrity, equity, and profitability (Niles, Ahuja, Esquivel, Mango, Duncan, Heller, \& Tirado, 2017).

\section{Climate Change Vulnerability in Belize}

$\mathrm{F}$ Tocusing on Belize, there is evidence of climate change including a lack of rain, increased heat and sun exposure, offset rainy seasons, increased storm intensity, and an increase in pests and crop diseases; these changes were perceived to have direct and indirect impacts to resident health, livelihoods, resource security, cultural traditions, and compounding environmental impacts (Drexler, 2019). Communities in Belize are vulnerable to these direct impacts, which are compounded by factors such as deforestation, agriculture activity (i.e., the use of chemical inputs of pesticides and fertilizers), biodiversity loss, poverty, population growth, land degradation, and farming on degraded soils (Drexler, 2020; Flint, 2015; Oremo, 2013; Young, 2008; Meerman \& Cherrington, 2005 as cited in Chicas, Omine, \& Ford, 2016; Young, 2008). 
Because milpa farmers depend upon the ecosystem for their basic needs, whole communities are impacted from system change; thus, there are implications for community food and livelihood insecurity from climate change impacts (Lozada, 2014). "The impacts of climate change are expected to threaten the sustainability of social, economic, and ecological systems" in Belize (Richardson, 2009, p. 8). Largescale climate and ecosystem changes in southern Belize have distinct impacts on the environment, economy, food security, public health, culture, and other factors in Belizean milpa communities (Chicas, Omine, \& Ford, 2016; Drexler, 2020); these impacts perpetuate a cycle of environmental degradation, poverty, and vulnerability to climate and ecosystem changes (Wildcat, 2013).

\section{The Milpa Farming System}

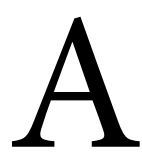

milpa is a small-scale shifting cultivation system of subsistence farming (Downey, 2009; Nigh \& Diemont, 2013) traditionally involving slash-and-burn and/or slashand-mulch practices (Johnston, 2003; Thurston 1997). The milpa is a significant aspect of Maya culture and tradition as Maya identity, ceremony, community, and livelihood are all rooted in the milpa (De Frece \& Poole, 2008; Falkowski, Chankin, Diemont, \& Pedian, 2019). Milpa crop production is used for subsistence and selling at local markets (Downey, 2009; Emch, 2003; Levasseur \& Olivier, 2000; Nigh \& Diemont, 2013). Milpa practices include clearing small areas of forest to plant a diversity of crops-primarily corn, beans, and squash-on nutrient-rich soil (Emch, 2003; Mt. Pleasant, 2016).

For centuries, the traditional practice of milpa farming has been sustainable and reliable as the major food and livelihood source for Maya milpa communities in southern Belize (Altieri \& Toledo, 2011; Benitez, Fornoni, Garcia-Barrios, \& López, 2014; Ford \& Nigh, 2016; Nigh \& Diemont, 2013) as farmers allow areas to regenerate to a mosaic of forest succession stages and crop diversity (Daniels, Painter, \& Southworth, 2008; Isakson, 2007; Mt. Pleasant, 2016; Shal, 2002). In the last 50 years, however, the slash-and-burn aspect of milpa farming has become less reliable and less sustainable due to hydroclimatic changes (i.e., droughts, flooding, hurricanes), forest loss, pests and crop disease, soil degradation, and social factors such as poverty, population growth, land tenure, marginalization, and other factors (De Frece \& Poole, 2008; Downey, 2009; Drexler, 2020; Levasseur \& Olivier, 2000; Lozada, 2014; New Agriculturist, 2005; Shal, 2002; Steinberg, 1998).

\section{Planetary Benefits of Climate-smart Practices on Milpa Farms in Belize}

mall-scale farms practicing cli-
mate-smart agriculture can have
a planetary-scale system benefit,
including to global climate change and
related impacts (Altieri, 2008). Cli-
mate-smart agriculture (CSA) practices
aim to "increase productivity in an en- 
vironmentally and socially sustainable way, to strengthen farmers' resilience to climate change, and to reduce agriculture's contribution to climate change" (Oremo, 2013, p. 14). Examples of CSA practices already proposed or being practiced on a small-scale in southern Belize include mulching and soil nutrient enrichment. Adopting CSA in Belize practices can enhance small farmers' adaptation to climate change and sustainably mitigate climate change impacts and support food security under a changing climate (FAO, 2013; Hellin \& Fisher, 2019; Kongsager, 2017; Mugambiwa \& Tirivangasi, 2017).

By examining climate-smart adaptive practices of Belize milpa farmers, one can see system influences of the small-scale practices with both micro-scale impacts (i.e., less site erosion, lower input costs) and macro-scale implications on Earth systems sustainability. Promoting the increase of CSA practices on traditional milpa practices such as mulching and soil nutrient enrichment can have overall positive environmental, economic, and socio-cultural influences and adaptive technology potential on milpa sustainability and resilience, as perceived by milpa farmers and Extension officers (Drexler, 2020; Ong \& Kho, 2015).

\section{Conclusion}

$\mathrm{I}$ $t$ is critical for governments to implement planetary sustainability measures, taking into account the SDGs and socio-ecological systems framework, to mitigate future climate change impacts on both micro- and macro-levels. The socio-ecological system impacts of climate-smart agriculture adaptions to small-scale milpa agriculture in Belize has implications for sustainability on an Earth system level. Although milpa farming has been sustainable for centuries, global climate change and other factors such as poverty, population growth, and forest loss have made the practice less so over the last 50 years. Promoting the increase of CSA practices such as mulching and soil nutrient enrichment has overall positive environmental, economic, and socio-cultural influences and adaptive technology potential on milpa sustainability and resilience, as perceived by milpa farmers and Extension officers (Drexler, 2020).

With the ability of space-based observation to predict climate change impacts and mitigation, the technology potential of space-based observations will be critical for food and livelihood security of not just Belize milpa farmers as found in this case, but other global farmers as well. Since farmers rely directly on SES systems (water, climate, soil nutrients, markets, governance and policies), they are invested stakeholders and should partners in solution-finding processes. CSA adaptive practices at the milpa farming community-level have positive SES indications that can be applied at the planetary systems level with wider implications for more sustainable global farming systems, food and livelihood security, and resiliency to climate change impacts. 


\section{References}

Adger, W.N. (2003). Social capital, collective action and adaptation to climate change, Economic Geography, 79(4), 387-404.

Altieri, M. A. (2008). Small farms as a planetary ecological asset: five key reasons why we should support the revitalisation of small farms in the global south. Penang, Malaysia: Third World Network.

Altieri, M. A., \& Toledo, V. M. (2011). The agroecological revolution in Latin America: Rescuing nature, ensuring food sovereignty and empowering peasants. Journal of Peasant Studies, 38(3), 587-612. https://doi.org/10.1080/03066150.201 1.582947.

Aminzadeh, S. C. (2006). A moral imperative: the human rights implications of climate change. Hastings Int'l \& Comp. L. Rev., 30, 231.

Benitez, M., Fornoni, J., Garcia-Barrios, L., \& López, R. (2014). Dynamical networks in agroecology: The milpa as a model system. In M. Benítez, O. Miramontes, \& A. Valiente-Banuet (Eds.), Frontiers in ecology, evolution and complexity. Mexico City: CopIt-arXives.

Campbell, B. M., Beare, D. J., Bennett, E. M., Hall-Spencer, J. M., Ingram, J. S., Jaramillo, F., ... \& Shindell, D. (2017). Agriculture production as a major driver of the Earth system exceeding planetary boundaries. Ecology and Society, 22(4).

Campbell, B. M., Hansen, J., Rioux, J., Stirling, C. M., \& Twomlow, S. (2018). Urgent action to combat climate change and its impacts (SDG 13): transforming agriculture and food systems. Current opinion in environmental sustainability, 34, 13-20.

Chaudhary, A., Gustafson, D., \& Mathys, A. (2018). Multi-indicator sustainability assessment of global food systems. Nature communications, 9(1), 1-13.

Chicas, S. D., Omine, K., \& Ford, J. B. (2016). Identifying erosion hotspots and assessing communities' perspectives on the drivers, underlying causes and impacts of soil erosion in Toledo's Rio Grande Watershed: Belize. Applied Geography, 68, 57-67. https://doi.org/10.1016/j.apgeog.2015.11.010.

Daniels, A. E., Painter, K., \& Southworth, J. (2008). Milpa imprint on the tropical dry forest landscape in Yucatan, Mexico: Remote sensing \& field measurement of edge vegetation. Agriculture, Ecosystems \& Environment, 123(4), 293-304. https:// doi.org/10.1016/j.agee.2007.07.003.

De Frece, A., \& Poole, N. (2008). Constructing livelihoods in rural Mexico: Milpa in Mayan culture. Journal of Peasant Studies, 35(2), 335-352. https://doi. 
org/10.1080/03066150802151090.

Downey, S. S. (2009). Resilient networks and the historical ecology of Q'eqchi Maya swidden agriculture (Doctoral dissertation). University of Arizona, Tucson. http:// hdl.handle.net/10150/195686

Drexler, K. (2019). Extension leadership and sustainable agriculture in Belize forest farming communities: A socio-ecological systems approach (Doctoral dissertation). New Mexico State University, Las Cruces, New Mexico.

Drexler, K. (2020). Government extension, agroecology, and sustainable food systems in Belize milpa farming communities: A socio-ecological systems approach. Journal of Agriculture, Food Systems, and Community Development, 9(3), 85-97. https://doi.org/10.5304/jafscd.2020.093.001

Durrieu, S., \& Nelson, R. F. (2013). Earth observation from space-The issue of environmental sustainability. Space Policy, 29(4), 238-250.

Emch, M. (2003). The human ecology of Mayan cacao farming in Belize. Human Ecology, 31(1), 111-131. https://doi.org/10.1023/A:1022886208328.

Falkowski, T. B., Chankin, A., Diemont, S. A., \& Pedian, R. W. (2019). More than just corn and calories: A comprehensive assessment of the yield and nutritional content of a traditional Lacandon Maya milpa. Food Security, 11(2), 389-404. https://doi.org/10.1007/s12571-019-00901-6.

Flint, R. W. (2015). Belize pollution problems. Retrieved from the Sustainability Now For Belize, C.A., website, archived at https://web.archive.org/ web/20160420132354/http://sustainability-now.org/belize-pollution-problems/.

Food and Agricultural Organization of the United Nations (FAO). (2010). Brief profile of the agriculture sector (Belize). Retrieved from http://www.fao.org/climate change/download/28928-0e0bc49fd6e72690e82c4c3b9d4dc6f52.pdf.

Food and Agricultural Organization of the United Nations (FAO). (2013). Climate-Smart Agriculture Sourcebook. Food and Agriculture Organization of the United Nations Report. Retrieved March, 2020 from http://www.fao.org/3/i3325e/ i3325e.pdf.

Ford, A. \& Nigh, R. (2016). The Maya forest garden: Eight millennia of sustainable cultivation of the tropical woodlands. London \& New York: Routledge. https://doi. org/10.4324/9781315417936.

Galli, A., \& Losch, A. (2019). Beyond planetary protection: What is planetary sustainability and what are its implications for space research? Life sciences in space research, 23, 3-9. 
Government of Belize (GOB). (2013). The national food and agriculture policy (2002-2020): No farmer=no food. Ministry of Agriculture and Fisheries. Retrieved from http://agriculture.gov.bz/wp-content/uploads/2017/05/Policy-Document1. pdf.

Hellin, J., \& Fisher, E. (2019). Climate-smart agriculture and non-agricultural livelihood transformation. Climate, 7(4), 48.

Isakson, S. R. (2007). Between the market and the milpa: Market engagements, peasant livelihood strategies, and the on-farm conservation of crop genetic diversity in the Guatemalan highlands (Doctoral dissertation). University of Massachusetts Amherst. Available from Proquest, AAI3289202.

Johannessen, J. A. (2009). Spaceborne observations of a changing Earth-Contribution from ESÁ s operating and approved satellite missions. EGUGA, 11882.

John, L., \& Firth, D. (2005). Water, watersheds, forests and poverty reduction: A Caribbean perspective. International Forestry Review, 7(4), 311-319. https://doi. org/10.1505/ifor.2005.7.4.311.

Johnston, K. J. (2003). The intensification of pre-industrial cereal agriculture in the tropics: Boserup, cultivation lengthening, and the Classic Maya. Journal of Anthropological Archaeology, 22(2), 126-161. https://doi.org/10.1016/S02784165(03)00013-8.

Kongsager, R. (2017). Barriers to the adoption of alley cropping as a climate-smart agriculture practice: lessons from maize cultivation among the Maya in southern Belize. Forests, 8(7), 260.

Koutsouris, A. (2008). Higher education facing sustainability: The case of agronomy. International Journal of Learning: Annual Review, 15(4), 269-276. https://doi. org/10.18848/1447-9494/CGP/v15i04.

Lal, R. (2008). Soils and sustainable agriculture: A review. Agronomy for Sustainable Development, 28(1), 57-64. https://doi.org/10.1051/agro:2007025.

Levasseur, V., \& Olivier, A. (2000). The farming system and traditional agroforestry systems in the Maya community of San Jose, Belize. Agroforestry Systems, 49(3), 275-288. https://doi.org/10.1023/A:1006327403980.

Lozada, S. B. (2014). Securing food and livelihoods: opportunities and constraints to sustainably enhancing household food production in Santa Familia Village, Belize (Master's thesis). University of Montana, Missoula. Retrieved from https://schol arworks.umt.edu/etd/4202/.

Marino, R., Atzori, A. S., D'Andrea, M., Iovane, G., Trabalza-Marinucci, M., \& Rinaldi, L. (2016). Climate change: Production performance, health issues, green- 
house gas emissions and mitigation strategies in sheep and goat farming. Small Ruminant Research, 135, 50-59.

Mazumdar, S. (2008). Geographic information systems in the application of precision agriculture for sustainable sugarcane production in the Republic of Panama. (Master's thesis). McGill University, Montreal, Quebec. https://escholarship.mc gill.ca/concern/theses/6q182n86q

Méndez, V. E., Bacon, C. M., \& Cohen, R. (2013). Agroecology as a transdisciplinary, participatory, and action-oriented approach. Agroecology and Sustainable Food Systems, 37(1), 3-18.

Molnar, S., \& Molnar, I. M. (2000). Environmental change and human survival. Upper Saddle River, NJ: Prentice Hall.

Morton, J. F. (2007). The impact of climate change on smallholder and subsistence agriculture. Proceedings of the national academy of sciences, 104(50), 19680-19685.

Mt. Pleasant, J. (2016). Food yields and nutrient analyses of the Three Sisters: A Haudenosaunee cropping system. Ethnobiology Letters, 7(1), 87-98. https://doi. org/10.14237/ebl.7.1.2016.721.

Mugambiwa, S. S., \& Tirivangasi, H. M. (2017). Climate change: A threat towards achieving'Sustainable Development Goal number two'(end hunger, achieve food security and improved nutrition and promote sustainable agriculture) in South Africa. Jàmbá: Journal of Disaster Risk Studies, 9(1), 1-6.

NASA (2014). Our vision for planetary sustainability. Online report. Retrieved December, 20, 2020 from https://www.nasa.gov/content/planetary-sustainabilityour-vision/.

Nigh, R. \& Diemont, S. A. (2013). The Maya milpa: Fire and the legacy of living soil. Frontiers in Ecology and the Environment, 11(1), 45-54. https://doi. org/10.1890/120344.

Niles, M. T., Ahuja, R., Esquivel, J. M., Mango, N., Duncan, M., Heller, M., \& Tirado, C. (2017). Climate change and food systems: Assessing impacts and opportunities.

New Agriculturist. (2005). Country profile-Belize. Retrieved from http://www. new-ag.info/en/country/profile.php?a=847.

Olsson, P., Folke, C., \& Berkes, F. (2004). Adaptive co-management for building resilience in social-ecological systems. Environmental Management, 34(1), 75-90. https://doi.org/10.1007/s00267-003-0101-7. 
Ong, C. K., \& Kho, R. M. (2015). A framework for quantifying the various effects of tree-crop interactions. In C. K. Ong, C. R. Black, \& J. Wilson (Eds.), Tree-crop interactions, 2nd edition: Agroforestry in a changing climate (pp. 1-23). CABI International. https://doi.org/10.1079/9781780645117.0001.

Oremo, F. Okumu. (2013). Small-scale farmers' perceptions and adaptation measures to climate change in Kitui County, Kenya (Master's thesis). University of Nairobi, Kenya.

Ostrom, E. (2009). A general framework for analyzing sustainability of social-ecological systems. Science, 325(5939), 419-422. https://doi.org/10.1126/sci ence.1172133.

Parrott, L., Chion, C., Gonzalès, R., \& Latombe, G. (2012). Agents, individuals, and networks: Modeling methods to inform natural resource management in regional landscapes. Ecology and Society, 17(3). https://doi.org/10.5751/ES-04936-170332.

Pass, J., Dudley-Rowley, M., \& Gangale, T. (2006). The cultural imperative to colonize space: an astrosociological perspective. In Space 2006 (p. 7488).

Pérez-Escamilla, R. (2017). Food security and the 2015-2030 sustainable development goals: From human to planetary health: Perspectives and opinions. Current developments in nutrition, 1(7), e000513.

Ratima, M., Martin, D., Castleden, H., \& Delormier, T. (2019). Indigenous voices and knowledge systems-promoting planetary health, health equity, and sustainable development now and for future generations.

Richardson, R. (2009). Belize and Climate Change: The Costs of Inaction. Human Development Issues Paper. United Nations Development Programme. Retrieved from https://www.undp.org/content/dam/belize/docs/UNDP\%20BZ\%20Publica tions/Belize-and-Climate-Change-The-Costs-of-Inaction.pdf.

Rockström, J., Steffen, W., Noone, K., Persson, Å., Chapin III, F. S., Lambin, E., ... \& Nykvist, B. (2009). Planetary boundaries: exploring the safe operating space for humanity. Ecology and society, 14(2). Also in Rockström, J., Steffen, W., Noone, K., Persson, Å., Chapin, F. S., Lambin, E. F., ... \& Nykvist, B. (2009). A safe operating space for humanity. Nature, 461(7263), 472-475.

Schmidhuber, J., \& Tubiello, F. N. (2007). Global food security under climate change. Proceedings of the National Academy of Sciences, 104(50), 19703-19708.

Shal, V. (2002). The Mayas and their land (Report No. 489). Belize Development Trust. Retrieved from https://ambergriscaye.com/BzLibrary/trust489.html.

Selomane, O., Reyers, B., Biggs, R., \& Hamann, M. (2019). Harnessing insights from social-ecological systems research for monitoring sustainable development. 
Sustainability, 11(4), 1190.

Sikula, N. R., Mancillas, J. W., Linkov, I., \& McDonagh, J. A. (2015). Risk management is not enough: a conceptual model for resilience and adaptation-based vulnerability assessments. Environment Systems and Decisions, 35(2), 219-228.

Steinberg, M. K. (1998). Political ecology and cultural change: Impacts on swidden-fallow agroforestry practices among the Mopan Maya in southern Belize. The Professional Geographer, 50(4), 407-417. https://doi.org/10.1111/0033-0124.00129.

Tandon, H. (2014). Strengthening sustainable agriculture in the Caribbean. A report for the FAO. Retrieved from https://competecaribbean.org/wp-content/uploads/2015/02/Strengthening_Sustainable_Agriculture_in-the-Caribbean_web. pdf.

Thurston, H. D. (1997). Slash/mulch systems: Sustainable methods for tropical agriculture. Boulder, CO. Westview.

Tsosie, R. (2009). Climate change, sustainability and globalization: charting the future of indigenous environmental self-determination. Envtl. \& Energy L. \& Pol'y J., $4,188$.

University of California-Davis (UC-Davis) (n.d.). What is sustainable agriculture? Web page. Agriculture Sustainability Institute. Retrieved from http://asi.ucdavis. edu/programs/sarep/about/what-is-sustainable-agriculture.

Uusitalo, V., Kuokkanen, A., Grönman, K., Ko, N., Mäkinen, H., \& Koistinen, K. (2019). Environmental sustainability assessment from planetary boundaries perspective-A case study of an organic sheep farm in Finland. Science of the total environment, 687, 168-176.

Vermeulen, S. J., Campbell, B. M., \& Ingram, J. S. (2012). Climate change and food systems. Annual review of environment and resources, 37.

Wildcat, D. R. (2013). Introduction: climate change and indigenous peoples of the USA. Climate Change and Indigenous Peoples in the United States, 1-7. Springer.

Wezel, A., Bellon, S., Doré, T., Francis, C., Vallod, D., \& David, C. (2009). Agroecology as a science, a movement and a practice. A review. Agronomy for Sustainable Development, 29(4), 503-515. https://doi.org/10.1051/agro/2009004

Young, C. A. (2008). Belize ecosystems: Threats and challenges to conservation in Belize. Conservation Letter. Tropical Conservation Science, 1(1), 18-33. Retrieved from https:// tropicalconservationscience.org. 


\section{Author Biography}

Dr. Kristin Drexler is a full-time Asst Professor teaching Geography, Environmental Science, and Conservation of Natural Resources for American Public University System (APUS) School of STEM. Drexler earned her Ph.D. in Educational Leadership at New Mexico State University (NMSU). She earned her Master of Arts from Ohio University. Since 2009, Drexler has conducted community surveys in Belize in agroforestry, conservation, and sustainable agriculture. Drexler was an Environmental Scientist in New Mexico (2003-2009), conducting field biology surveys and environmental impact analyses. Awards: Drexler earned 2020's Undergraduate Teaching Excellence Award, APUS-School of STEM; Drexler won the NMSU Globalization Award for founding the Belize Field School Program, a series of short field courses in Belize in wildlife, marine biology, agriculture, and documentary filmmaking (2006-2014). In 2016, Drexler produced an award-winning short film, "Yochi," a story about youth conservation action against wildlife poaching. Service: In the late 1990s, Drexler served as a Peace Corps Volunteer in Belize. She serves on the board of directors of Full Basket Belize, a U.S. nonprofit that provides scholarships and community grants in Belize. 